\title{
The Effect of STAD Type Learning Model on the Results of Learning in Term of Critical Thinking Skills of Vocational School Students
}

\author{
Lutfiana Sa'adatul Fuad*, Dewi Anggreini \\ Department of Mathematics Education, STKIP PGRI Tulungagung \\ Jl. Mayor Sujadi Timur No. 24 Plosoklandang Kedungwaru Tulungagung, 66229 \\ "Email: Lutfianasaadatul@gmail.com
}

\begin{abstract}
This study aims to look at the effect of learning model STAD type on learning outcomes in terms of the ability to think critically. The research was conducted at SMK Negeri 1 Kras with X-class population is much 272 students and samples were taken by purposive sampling. Collecting data using the test method. Data were analyzed using a two-way ANOVA test. The conclusion of this study:(1) There are significant differences mathematics influence learning outcomes among students who take STAD learning model with conventional learning models, (2)There are significant differences influence the ability of critical thinking among students who take STAD learning model with conventional learning model,(3) There are significant differences influence interaction between STAD learning model with conventional learning models in terms of the ability to think critically about mathematics learning outcomes.
\end{abstract}

Keywords: Conventional, Critical thinking, Results learning, STAD, Trigonometry

\section{INTRODUCTION}

Education is actually a complex sequence of events, The event is a series of inter-human communication in order to grow as a whole person (Hudojo, 1990: 1). Mathematics is one of the basic science that has a considerable role both in everyday life and in the development of science and technology. Besides mathematics is a means to think logically and with more knowledge of mathematics can be developed rapidly. Thus mathematics occupy themselves as a means of strategies to develop skills and intellectual skills.

In Permendiknas number 22 of 2006 on the Content Standards for Primary and Secondary Education Unit stated that mathematics is a universal science that underlies the development of modern technology, have an important role in a variety of disciplines and develop the power of human thought. Ministry of Education gave a serious emphasis on mathematics education at all levels of education, from elementary school (SD) to the university. Although the human civilization is changing rapidly, the mathematics continue to be relevant and support the changes. Mathematics is a universal science that underlies the development of modern technology, has an important role in a variety of disciplines and human cognitive development.

Learning is a complex process, not just a teacher conveying the material but also the teacher in charge, directing and teachers must create an atmosphere that encourages students to follow the spirit of learning. There are still many students who are less interested in the subject in particular math (Trizulfianto, Goddess A. \& Adi $W, 2017)$.

Actually learn not just think it, because when people are learning, then people who are learning the undertaking various activities, such as observing, comparing, doubt, love, passion, and so on. The fact the field is often positioned as a subject teacher and pupil as an object so that the learning process is only one path. This causes learning becomes boring, and the impact on students' lack of understanding, lack of interaction and also fewer trigger students to think critically so that students learn less than optimal results.

Many reasons make cooperative learning is used in the education system, Slavin (2009) suggests two reasons, first, some studies show that the use of cooperative learning can enhance the learning achievement of students, can develop social relationships, fostering acceptance shortage of self and others as well can improve self-esteem. Second, cooperative learning can realize the need for students to learn to think, solve problems, and integrating and applying knowledge with their skills.

Slavin was quoted in (Trianto 2009) states that the STAD students are placed in learning teams membered 4-5 people who are a mixture according to the level of achievement, gender, and ethnicity. The teacher presents a lesson, and then students work on their team to make sure that all team members have mastered the lesson. Then, all students are given a test on the material, at the time of this test they are not allowed to help. As with other learning, STAD cooperative learning also requires considerable preparation of learning activities implemented.

Critical thinking in learning mathematics is a cognitive process someone in an attempt to mathematical knowledge based mathematical reasoning (Syahbana, 2012). Critical thinking is the ability to for to think effectively that can help a person to make, evaluation, and make decisions according to what he believes (Idham K., Aulia A., Alsavira S., \& Rahmati N, M., 2017). So critical thinking can conclude the process by which someone responds, concluded a 
problem that is acceptable and can manage them with the precision that will emerge a new thinking on our own thoughts.

\section{MATERIALS AND METHODS}

The design uses the type of research that is quasiexperimental (Quasi-Experimental Design). According to (Sugiyono, 2015, p. 108) suggests a quasi-experimental (Quasi-Experimental Design) has the control group but not able to function fully to control external variables that affect the implementation of the experiment. Researchers can not control all of the variables that could affect the implementation of the experiment, so the researchers used a pseudo-study which only controls the learning outcomes of students while in class regardless of the variables that could affect student learning outcomes.

The population in this study were all students of class $\mathrm{X}$ SMK 1 Kras consisting of 8 classes. Eighth grade consisted of as many as three classes TKJ class, TKR classes and classes for 3 Hospitality much as 2 classes with the total number of class $\mathrm{X}$ is 272 students, consisting of boys and girls. Male students a total of 150 children and 122 women students a number of children.

According to (Sugiono, 2015, p.60) research variable is an attribute or trait or value of space, objects or activities that have a certain variation defined by the researchers to learn and then be deduced.

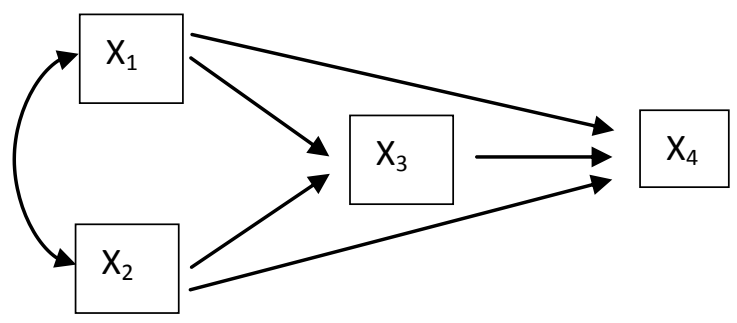

Figure 1. Research design. Source: analysis research (2018).

Design in figure 3.1, there are two groups, each of which were selected purposively. The first class is treated $\left(\mathrm{X}_{1}\right)$ and the other group was treated $\left(\mathrm{X}_{2}\right)$. Classes are treated $\left(\mathrm{X}_{1}\right)$ is called the experimental class and treated $\left(\mathrm{X}_{2}\right)$ is called a control class. The influence of the treatment is $\left(\mathrm{X}_{3}\right)$ is the ability to think critically and $\left(\mathrm{X}_{4}\right)$ learning outcomes. Research by the effect of treatment was analyzed by two-way ANOVA.

\section{RESULTS AND DISCUSSION}

Where the results of learning mathematics trigonometry materials described experimental class students with $\mathrm{X}_{11}$ and $\mathrm{X}_{12}$ control class described with, and critical thinking ability test results of material trigonometry class students experiment described with $\mathrm{X}_{21}$ and $\mathrm{X}_{22}$ control class described with and can be described as follows:

a) Results Data section Math Class Experiments $\left(\mathrm{X}_{11}\right)$
The number of students of class $\mathrm{X}$ TKJ 1 as an experimental class who took the tests on as many as 35. Based on the collected data obtained mean $=$ 85.86; median $=88.00 ;$ mode $=90 ;$ variance $\left(\mathrm{s}^{2}\right)=31$ 067; standard deviation ( $\mathrm{s})=5574$; Maximum value =98; and the minimum value $=72$,

b) Math Class Result Data Control $\left(\mathrm{X}_{12}\right)$

The number of students of class X TKJ 3 as the control class who took the tests in as many as 35 students. From the collected data obtained mean $=75.54$; median $=76.00 ;$ mode $=78 ;$ variance $\left(\mathrm{s}^{2}\right)=33373$; standard deviation (s) =5777; Maximum value $=88$; and the minimum value $=64$,

c) Critical Thinking Ability Test Results Class Experiments Data (X21)

The number of students of class X TKJ 1 as an experimental class who took the tests on as many as 35. Based on the collected data obtained mean $=$ 81.03; median $=80.00 ;$ mode $=80 ;$ variance $\left(\mathrm{s}^{2}\right)=50$ 499; standard deviation (s) $=7106$; Maximum value $=98 ;$ and the minimum value $=64$,

d) Critical Thinking Ability Test Results Grade Control Data (X22).

The number of students of class X TKJ 1 as an experimental class who took the tests on as many as 35 . Based on the collected data obtained mean $=56.49$; median $=58.00 ;$ mode $=55 ;$ variance $\left(\mathrm{s}^{2}\right)=202728 ;$ standard deviation $(\mathrm{s})=14$ 238; Maximum value $=78$; and the minimum value $=32$,

Analysis of the data in accordance with (1) Test Prerequisites consisting of Normality Test and Test of Homogeneity. (2) Test the hypothesis using a two-way ANOVA test.

Based on calculations using SPSS 17 obtained significance value achievement test instrument reliability is 0,641 which is then given the interpretation of Cronbach's Alpha reliability level is > 0.6 to 0.8 which generate significant value therefore means that the test instrument including reliable / unreliable and indexes the reliability of critical thinking ability test instrument is 0.869 Furthermore, given the interpretation of the level of reliability Cronbach's Alpha is $>0.6$ to 0.8 which generate significant value, therefore, means that the test instruments including highly reliable / very reliable. $>0$, 60.

Prior to prove the hypothesis, then the steps that need to be done first is to test the prerequisite that is used is the test for normality and homogeneity. This research normality test using SPSS 17 TestOne Sample Kolmogorov-Smirnov Test and homogeneity test using the Test F with $\alpha=0.05$. Normality test is done to see samples of normal distribution or not. Based on $F$ test obtained significant value TKJ class I is 0.304 and TKJ class III is 0,407 , then given the interpretation of the value of $\alpha=0.05$, then the group of learning outcomes and the ability to think critically $>0.05$ so that the two groups of the normal distribution.

Homogeneity test is used to determine whether the variances of a number of the same population or not. In this study the homogeneity of variance for the population used is the F test using one way ANOVA test using SPSS 17 as follows: With significant value is 0.542 with a 
value of $\alpha=0.05$, then given the interpretation of the value of $\alpha=0.05,0.542>0.05$, it can be concluded that that the variances of the same or a homogeneous population.

The hypothesis using two-way ANOVA consists of two factors/ treatment/variable. Based on data from the calculation of SPSS 17 with a value of $\alpha=0.05$, then given the interpretation of the value of $\alpha=0.05$, it can be concluded that significant value is $0.710>0.05$, then the variant group of learning outcomes and the ability to think critically compared to the same or homogeneous. So the assumption of homogeneity in the two-way ANOVA test is met. The next test or two-way ANOVA test. Based on data from the calculation of SPSS 17 with a value of $\alpha=$ 0.05 , the significance of both models is 0,026 , it can be concluded that significant value is $0.026<0.05$, compared variants of the model group which "differs" significantly. So thank ANOVA testH1 namely that there is a significant difference influence mathematics learning outcomes among students who take models Learning Student Teams Achievement Division (STAD)with conventional learning models in class X SMK 1 Kras.

Based on data from the calculation of SPSS 17 with a value of $\alpha=0.05$ level of significance value of critical thinking ability of the two classes is 0,003 , it can be concluded the significant value of critical thinking skills level of $0.003<0.05$, compared variant class group which "differs" significantly, So thank ANOVA test H1 namely that there is a significant difference influence the ability of critical thinking among students who take models Learning Student Teams Achievement Division (STAD) with conventional learning models in class X SMK 1 Kras.

Based on data from the calculation of SPSS 17 with a value of $\alpha=0.05$, the significance of both models is 0,036 , it can be concluded the significant value model comparison and the ability to think critically is 0.036 $<0.05$, ANOVA test thanksH1ie no influence interaction significant between models Learning Student Teams Achievement Division (STAD) with conventional learning models in terms of critical thinking ability to mathematics learning outcomes in class X SMK 1 Kras.

\section{CONCLUSIONS}

From the study, it can be concluded that:

1. There is effect significant mathematics learning outcomes among students who take the learning model Student Teams Achievement Division (STAD) with conventional learning models in class X SMK 1 Kras.

2. There is influence significant the ability of critical thinking among students who take the learning model Student Teams Achievement Division (STAD) with conventional learning models in class X SMK 1 Kras.

3. There is an effective interaction significant between learning model Student Teams Achievement Division (STAD) with conventional learning models in terms of critical thinking skills to the learning outcomes of mathematics in class X SMK 1 Kras.

\section{REFERENCES}

Hudojo, H. 1990. Mathematics Teaching and Learning Strategies. Malang: Teachers' Training.

Idham Khaliq, Aulia Azzahra, Alvira Safitri and Nurul Rahmati M. 2017. "Efforts to Improve Critical Thinking Mathematically Students Using Contextual Socratic Method". Fibonacci: Journal of Mathematics and Mathematics Education. Vol. 3 (1), pp: 23-30.

Measuring Capabilities Critical Thinking Mathematically Students SMP. Edumatic. 02 (01). 45-57. The Muhammadiyah University of Bengkulu.

Trianto. 2009. Design Innovative-Progressive Learning Model: Platform Concept, and Implementation Unit Level Curriculum $(S B C)$. Jakarta: KENCANA Prenada MEDIA GROUP.

Trizulfianto, Dewi Anggreini, and Adi Waluyo. 2017. Analysis of Difficulty Students In Mathematics Creative Problem Solving Linear Program Based on Student Learning Styles. UNION: Journal of Mathematics Education. Vol 5 No 2

National Education Minister Regulation No. 22 The year 2006 About the Content Standard for Primary and Secondary Education.

Slavin, RE 2009. Cooperative learning: theory, research, and practice. Translated by Nurlita. 2005 Bandung: Nusa Media.

Sugiyono. 2015. Qualitative and Quantitative Research Methods $R$ $\& D$. Bandung: Alfabeta. 
THIIS PA GE INTENTIONALLY LEFT BLANK 